\title{
Causes of Poor Service Delivery and the Feasibility of Outsourcing to Improve Services in Local Authorities
}

\author{
${ }^{1 *}$ Wadesango N, ${ }^{2}$ Mhaka C, ${ }^{2}$ Chikomo, T., ${ }^{1}$ Wadesango V.O \\ ${ }_{1}^{1}$ University of Limpopo, Centre for Academic Excellence, Limpopo, RSA \\ ${ }^{2}$ Midlands State University, Faculty of Commerce, Zimbabwe \\ *newman.wadesango@ul.ac.za
}

\begin{abstract}
This theoretical paper was undertaken to ascertain the causes of poor service delivery and to establish if outsourcing of public service delivery could be used to improve local Authority services. It interrogated and critiqued documents on what other researchers in their different contexts had established in view of the feasibility of outsourcing as a strategy to improve service delivery. It emerged in this study that political interference, lack of citizen participation. lack of funds and corruption were the main causes of poor service delivery in local authorities. Therefore, outsourcing was seen to bring quality and affordable services for the public while costs savings and emergence of hidden costs were the financial implications unveiled for the local authorities (LAs). Social costs, accountability for public service delivery and quality shading were cited to be the outsourcing challenges. It also emerged in this study that outsourcing can increase service quality and provide affordable services for the public. Taking into account the information that was accumulated and examined, the researchers came to the conclusion that the current services being offered by local authorities are very poor and this is attributed to many causes such as political interference, lack of citizen participation, lack of funds and corruption. The study therefore, concludes that outsourcing could be a feasible option to use to improve service delivery by local authorities.
\end{abstract}

Keywords: Outsourcing, feasibility, public services, service delivery, local authority

\section{Introduction}

Different authors have researched on outsourcing of public services by local authorities and its effects on the quality of service delivery. Zhang and Sun (2012), Poutvaara (2014) investigated the effects of outsourcing of public services and concluded that this strategy in some states, in particular the USA, improved the quality of services. Accordingly, governments that suffer financial strains due to softening revenue may be feeling pressure to especially cut back non-core functions so they outsource them (Aik, 2012). However, Dolley (2014) and Kinyua (2015) argue that a few duties must rest with the state, including certifications of flexibility, social equity and accountability. It is against this backdrop that this research was conducted in order to ascertain whether outsourcing of public services can be adopted by local authorities in a developing country so as to improve the provision of public services.

The study adopted a desktop research methodology. It interrogated and critiqued documents on what other researchers in their different contexts had established in view of the feasibility of outsourcing as a strategy to improve service delivery.

\section{Causes of Poor Service Delivery by Local Authorities}

Political interference: Makanyeza (2015), identified political interference as one of the reasons for poor administration conveyance in local governments. Their research showed that the citizens postulated that political interference was the cause of poor service delivery showing a mean of 3.44 and a standard deviation of 1.097 from the other causes. Obert et al. (2014) explained that there are many cases where lawmakers utilize service delivery as support instruments and exploit their positions to pick gain support. There may be differences between the national and local government systems (LGs) and these will be a constraint to service delivery. Grossi and Mussari (2012) argue that interference by lawmakers in the organization circle of local authorities is a huge issue for the functioning of the local authorities. Chosen delegates do not have the vital skill to do capacities in a successful and effective way and in this way, may take after criteria of a political nature than a consistent and administrative thinking plan there by compromising quality of service delivery. Service delivery in local authorities is very poor. Tayaouna (2012) concurs that the degree on undue political obstruction in local government undertakings by either one of the central governments (state or federal) is 
troubling and needs revaluation. They went on to cite that local governments lack independence and are regularly considered as an extension of states service. Subsequently choices are taken by state governors and forced on the local governments for execution.

Centre-local relations between the parent ministry or government and the LGs are exceptionally concentrated (Kurdi, 2012). The Ministry of LG keeps all the control and power over the local authorities whereas this relationship is supposed to foster freedom and independence of the local authority. It has transformed into an ace subordinate relationship that has adversely influenced the benefits of service delivery. The authors went on to conclude that viable delivery of public services is disturbed by an abnormal state of ministerial obstruction in the choices of the municipalities. Too much politicization of the public sector, obstruction amongst government officials and administrator of LAs into the business of one another and vice versa has negative results on unit positioning which is spoiling the provision of services. However, Abe and Monisola (2014) argue that the absence of political interest obstructs the powerful provision of services and may also give an opportunity for the absence of straightforwardness and responsibility that is fundamental for productive utilization of accessible funds for the advantages of the general population in the community. Bazeley (2015) agreed that political motivations might as well have a bigger power on local authorities' choices regarding the management of urban water services, the influence is rather a positive one. Politicians have initiatives that are aimed at encouraging associations among local authorities so as to help improve their service delivery through the sharing of ideas and resources. After 1994, municipalities in South Africa were given more freedom and independence by the enactment as a third part of central government, this action provided local authorities a bigger developmental part to play in their communities (Majikijela, 2012). The enactment advised different methodologies that guaranteed that advancement adequately occurred in the nation including flexibility from political impact. Practically, these strategies and freedom have not proved to be a success. Implying that even with freedom from political interference local authorities still provide poor services.

Lack of funds: Goldsmith (2014) identified lack of funds as a cause for poor service delivery in local authorities. The authors further argue that the lack of financial resources makes service delivery problematic. LAs continue to depend on the decreasing financial assistance that comes from the central government which worsens their ability to provide the public services as the central government's funding cannot be reliable upon and it does not come during the exact period it is needed. The failure of residents to pay for the services rendered also translates to the lack of funds in local authorities. It also results in local authorities being owed thousands of dollars by the citizens. The ratepayers are evading due payments, denying the towns the muchneeded revenue, the local authorities then satisfy the human capital with hefty salaries at the expense of service delivery. The survey done by Makanyeza (2015) also supported that lack of funds or a poor revenue base as a cause for poor service delivery by local authorities showing a mean of 3.94 of the respondents votes with a standard deviation of 1,259 from the average of all the citied causes. Ame et al. (2013) citied that under-financing in local authorities is activated by fraud, delay in reporting and intensely relying upon benefactors. The under financing has caused many undesired results such as the powerlessness to give ideal social and economic services. Ame et al. research went on to conclude that citizens are aware of the misuse of funds in local authorities but they do not open up as they feel that whatever they say cannot change anything in the way the local authorities operate. Also, in study conducted by Tafirei (2012), it emerged that the major cause for poor service delivery is the shortage of financial resources.

Ibok (2014) asserts that for LAs to viably give basic services at the grassroots, empowering conditions must prevail. Particularly financial support must be accessible to complete its allocated duty. Non-provision of enough finances to LAs frustrates compelling execution by the LAs. Monetary requirements restrain the ability of the LAs to give better, productive and successful services. This notion was also supported by Majikijela (2012) who posits that there is an immediate connection between the payment for services and the provision of those services, which implies that if inhabitants pay their rates, local authorities will have financial support and would have the capacity to give services of higher quality. If occupants do not pay, then LAs would barely have the capacity to give services to its communities in light of the absence of funds. However, Adeyemi (2012) in Ejue and Madudueze (2014) advances that the poor service delivery at the rural areas was taking place during a time when large amounts of public monies were being allocated to local authorities. So the notion that the provision of quality public services is hampered by lack of financial 
resources does not hold water. This is also supported by Salam et al. (2012) who postulate that the lack of funds is no longer a constraint for local authorities in Nigerian service delivery but the misappropriation and mismanagement of the funds is a cause for concern. This is also supported by Hassan et al. (2013) who say that LA's execution by all means does not legitimize the monetary assets it has gotten from the federal account. The reasons behind the underperformance were said to extend from corruption to moderate and wasteful managerial procedures yet most critical is that individuals' input is forgotten in the designing of the policies. In Zimbabwe local authorities, Tafirei (2012) notes that the public service provision challenges hold on in spite of the government diverting expanding financial assistance to the LAs circle. The expanded funds going into the LA's circle have not converted into comparable service delivery enhancements in the larger part of municipalities. In this manner, infusing more funds is a necessary intervention but it may not be sufficient to solve all the challenges facing the sector.

Macanda (2014) in his research revealed that rural local municipalities have not been generating much revenue compared to the cities because of the nature of their business. The municipalities experience this challenge but it does not mean that the pace of rural development should not improve especially if we consider the democratic period and constitutional framework of South Africa that has been positive. The author went on to posit that in terms of section 152(2) in the constitution of the Republic of South Africa Act 108 of 1996 emphasized that municipalities should strive with its administration and financial capacity in order to achieve the objectives mandate in the constitution. This means that in whatever challenges the municipalities encounter, financially they have a responsibility to fulfil. Yeboah (2013) argue that service provision that is of low quality, poor view of administration frameworks, deficient capitalization, extraordinarily influenced the accumulation of income. Poor quality service delivery is some reason why local authorities are collecting low amounts of revenue. Yeboah (2013) then concluded that a positive correlation between the provision of services and ratepayers' ability to provide payments for the services enjoyed exists. When the provision of services improves, rate payers are more eager to make payments for the services. Lack of funds therefore, could not be necessarily the cause of poor service delivery but poor service delivery is the reason for the poor financial resources.

Corruption: Kinyua (2015) highlighted the implications of corruption in the local authorities of Nigeria saying that it robs local authorities of their financial strength to foster development and transformation in rural communities. Ejue and Madudueze (2014) advances that at the local government level, corruption has been given room to expand and even praised and the deteriorating standard of living of majority of the rural dwellers is evidence to the absence of good governance which is the antidote of corruption. Due to the privileged positions of the public servants to public resources and information, they tend to abuse these privileges to the detriment of the principles (Nigerian citizens). In their conclusion, they assert that the high rate of corruption in local authorities has great impact on service delivery. High rates of corruption mean that communities have their treasures that must be theirs to finance infrastructure and services taken away (Rom and Tukel, 2012; Wadesango and Mhaka, 2017). Abe and Monisola (2014) also added on that lack of straightforwardness and responsibility prompts corruption which may likewise be an explanation behind wasteful provision of public services for the general population in the communities. Where a LA is truthfully responsible to a nearby electorate it will have more motivation to enhance the service provision for which it is capable.

Majekodunmi (2012) postulates that LA is the nearest government to the general population so it is relied upon to assume a huge part in the provision of services for the general population with a specific end goal to enhance their way of life. Corruption has taken the central stage in most governments in Nigeria. Most internally generated revenues do not go to the local government account but is rather taken up by patrons of the ruling party and their clients. This leaves the local government worse off financially, depending on federal and state governments for funds to at least pay for monthly salaries for their workers putting developmental projects and programmes on hold. Blondal (2012) concurs by saying that corruption prevents building projects by local authorities from getting electricity, in this way making individuals from the general public battle to get electricity benefits in South Africa. The proceeding with eccentrics of the power supply can possibly cause major local authority provision of services disturbances. 


\section{Financial Implications of Outsourcing on LAs}

Cost saving: Blondal (2012) identified cost saving as a benefit of outsourcing. He explained that it is the bringing down of the general cost of the support of the business. It includes the score characterizing quality levels, negotiations, cost rebuilding and access to bring down cost economies through demonstrating work arbitrage.

Salam et al. (2012) highlighted that the advantage of outsourcing service delivery among others is cost reduction. Jensen and Stonecash (2012) went on to explain that the provision of services that is contracted out to companies in the private sector must lead to large savings in costs than the provision that is done inhouse. Their results showed that LAs had put garbage collection up for tenders and got into an agreement with companies in the private sector and thereby saving costs of up to a mean of $22 \%$ and the LAs that gave such an opportunity to an in-house group had a cost saving of $17 \%$ which indicates that competition that is experienced in the private sector has an impact on the reduction of expenses. Ketch (2013)'s study came to the conclusion that outsourcing facilitates the saving of costs than the provision of the services in house. Hodge 2000 in Ketch (2013) found that outsourcing produced saving of costs from $6 \%$ to $12 \%$ for LAs. The authors went on to say that there is a lot of research done by the government, scholars and others recommending that contracting out in a competitive manner brings about cost sparing in the scope of $5 \%$ to $50 \%$ upon the extension and kind of service. Grant and Ohemeng (2014) said that the make of the contract and monitoring results in magnified transaction expenses to be experienced by the LA when they outsource public service delivery. Local governments which do not have enough funds may not monitor the private provider as much as needed, this provides room for the private provider to act in a self-intrigue manner which may prompt increments in costs, bring down quality of services and bargains responsibility and straightforwardness. Grant and Ohemeng (2014) went on to illustrate that increasing monitoring increases overhead costs.

Ame et al. (2013) argue that outsourcing reduces costs by making once fixed cost variable costs and the avoidance of capital expenditure. The author later on mentioned that the challenges of outsourcing such as, the need for public sector organisations to measure performance, administer contracts and determine levels of responsibility or accountability can translate into high costs for the local authorities. Fernandez et al. (2012) highlighted that the argument for outsourcing of public services has clear disadvantages for the magnitude of the public workforce and public employment in that it reduces it. Outsourcing functions to the private sector saves money most of the time and most of the savings tend to disadvantage the employees of the local authorities. They went to cite that in order for the state and the local governments to decrease their expenditure, they have to reduce the workforce, that is the employees of the local governments will lose their jobs so that costs can be reduced. Poulfelt (2014) asserts that the theory of transaction costs expects that there will be low costs of production when an entity uses outside providers. In any case, the utilization of outer providers may bring about unsatisfactory product and service quality, while they may decline to adjust or may increase costs or up in different ways act artfully when they have the ability to do as such. This prompts higher exchange costs for the public sector that has chosen to outsource its public services. Johnson (2014) further highlighted that outsourcing has failed to meet the government's expectation of achieving financial savings due to hidden or unforeseen costs. Dolley (2014) agrees that at first outsourcing may paint a picture that it brings about cost savings but this later ends up being fanciful and as soon as a function is contracted out bringing it back in house can prove to be a troublesome and costly procurement of the skills that had been let go.

Emergence of hidden costs: Boris (2015) postulate that "the major disadvantage of outsourcing is that it surrenders control to the supplier, once a procedure has been given over to a private firm it will be costly to get it back in-house". The underlying contract may likewise be expensive yet the inescapable changes may even cost more. Kurdi (2012) also argue that outsourcing has the probability of having hidden costs and these may be legal costs incurred while signing an agreement between entities. The local authorities may need to dedicate excess amounts of effort and time to have agreements signed. Greenwood (2014) advances that there is mixed success with outsourcing public services and that while approximately half of all governments continue to explore new contracting, many are starting to bring service delivery back to in-house which is costly. Bazeley (2015) concurs that the provision of services by the private firms may cost more than was 
anticipated because of hidden costs or unforeseen costs. He brings to the fore that transactional costs are most of the time not considered when outsourcing decisions are made. These costs include vendor management costs which are incurred throughout the lifetime of an outsourcing function in order to monitor vendors and periodically re-negotiate their contractual obligations.

Poutfelt et al. (2014) argue that the results of outsourcing have not been the same for all LAs, as some LAs are reacting by bringing the provision of services back in-house. Cox et al. (2012) agree that there is need for the local authorities to compile a water tight contract and establish trust since it can prove to be hard and very expensive to alter the agreement. The provider will provide the services that the local authorities have demanded in the agreement and will bill extra expenses for any function that was not specified henceforth the importance for the local authorities to understand every aspect of the contract and write a water tight contract. Their research found that despite writing detailed and complete contracts, hidden costs always occurred. Rom and Tukel (2012) contend that there is a 'risk' of the local authorities getting unrealised savings rather that hidden costs. Kinyua (2015) concurs that contracting out has inherent risks and that these dangers come in forms of hidden costs of contracting out. In any case, he says that contracting out can give financial flexibility by changing fixed costs into variable costs. Johnson (2014) went on to say that the costs that are budgeted for outsourcing are always accurate and that hidden costs are ignored.

\section{Challenges of Outsourcing}

Accountability for public service delivery: Abe and Monisola (2014) assert that there is rising expectations of citizens and the increasingly complex environment that public agencies need to operate within the local governments can delegate the provision of services to the private sector through outsourcing but they cannot outsource or delegate their statutory responsibilities to provide public services. Therefore, the local governments remain responsible for functions that were done by the private vendors. There are consequences to this as the citizens can lose trust in the government for the service delivery failures. Grossi and Mussari (2012) argue that one of the most evident consequences of outsourcing service delivery to the private sector is that of the distribution of obligations between the local government and the private firm for the execution to be accomplished. LGs are left with the duty of characterizing and surveying composed approaches and techniques and ensuring that the supplier has clung to the agreement. The supplier must render the services in a productive and compelling way. They went on to infer that there is a requirement that LGs still be in charge of general society needs' satisfaction and to be taken capable and responsible for the private providers' work of outsourcing services. Boris (2015) also advances that even if local authorities outsource service delivery, they will always be accountable for the services. Accountability cannot be passed on to the private firm.

Irish et al. (2012) identified accountability as a challenge that comes with outsourcing public services to the private sector saying that reliance on private firms leads to lose of control on the part of the local authorities because the implementing organisations will, all the time, be in possession of knowledge on what is happening on the ground. LGs depending on the private firms will therefore have to agree to an unusual form of responsibility, one in which there is sharing of responsibilities for achieving the goals of the function and poor service delivery. Goldsmith (2014) argues that considering a local authority responsible for its conduct and execution is a continuing test in vote based frameworks of governments. Expanding utilization of contractual workers and systems of suppliers for the provision of services makes this all the more difficult. Tykkynen et al. (2012) also concluded in their study that failed monitoring may endanger the quality and consumers' safety may suffer if private providers employ staff that is not competent. It implies that the local authority will be answerable for this. Citizens and even elected representatives often lose access to critical information when services are outsourced to private contractors (Greenwood, 2014; Wadesango et al., 2017). Private contractors have rights to privacy that public organisations do not have and that have been upheld in numerous court cases. The secret contract negotiations are often rationalised as necessary to protect these rights to privacy. Therefore, when the private contractor provides low quality services, they cannot be accountable for these services but the local authorities are, as the citizens cannot demand information from the private contractor. Figgis and Griffith (2012) argue that offering tenders that are competitive and outsourced can increase the responsibility of LAs by putting pressure on them so that they indicate plainly all targets of the services and the obligations of the expert private service provider, making it simpler to 
distinguish who is in charge of various parts of the function. There are worries that outsourcing may decrease the responsibility of the LAs for contracted functions. Rom and Tekel (2012) cited that outsourcing promotes accountability. Deakin and Walsh in Rom and Tukel (2012) found that administrators in LAs by and large understand a positive change in responsibilities in the specific service contracted out.

Social costs: Dollery (2014) explained that if in the event that a vital local entity utilizing various local individuals is outsourced, this can set in motion capable negative multiplier impacts which incorporate uprooted public labourers to leave the region, along these lines bringing down populace, decreasing economic development and threatening the feasibility of other open and private administrations like state funded schools, banks and other offices. Greenwood (2014) established that outsourcing can include generously bringing down the wages and advantages for local government labourers, taking away money from nearby economies. Labourers getting less wages will spend less in their own local communities prompting many immediate and circuitous social effects. This fact was also supported by Tafirei (2012) when he said that private firms have to present the LAs with the lowest prices and this makes the private firms want to decrease their costs and they do this by reducing the pay for their employees. After a while, noticeable differences in the wages and standard of life among the employees may lead to huge social issues that will prompt the central government to intervene and help the low-income earners financially. The wages for some workers will even be lower that the legal minimum.

Ame et al. (2013) also mentioned various social costs which come about because of outsourcing. Labour exploitation was part of it citing under-pay, no salary increases and no career prospects as the factors under it. Additionally, they identified no job security, low staff morale, insufficient penalty to contractor and statutory minimum wage as other social costs. Boris (2015) also posits that maximising value for money in the provision for services makes up the benefit of contracting out. Local government will want to reduce their expenses and boost efficiency by making service delivery open to the competitive market. The reduction of expenditure will be archived by decreasing costs of labour compromising the working environment instead of making better input utilization. Workers will be deprived of industrial relations foundations; the general picture is commanded by a discontinuity of working conditions both as far as wages and employee-related advantages (annuities plan, paternity and maternity leave, sick pay) (Boris, 2015; Wadesango and Wadesango, 2016). Poutvaara (2014) argues that there is a general increase in dread for the loss of occupations in the public sector yet the exact proof for this dread is questionable. He went on to state in his study that most investigations have reasoned that the long-haul impact on employment is either intangible or positive, in spite of the fact that there may be here and now employment losses from contracting out the provision of public services.

Tayauova (2012) is of the view that often after outsourcing, a part of the team that was in the local government moves from the outsourcing party to the private firm. This shows that when there has been outsourcing, employees will simply be transferred to the private firm therefore, no loss in jobs. However, this is not possible for all outsourcing transactions as the private firms may have their own employees. Macanda (2014) suggests that besides wage differences and quality of life portrayal, a third factor likewise, assumes a vital part, which is the distinctive levels of legitimate legal insurance of workers in various nations. The distinction in representatives' lawful insurance in the public segment shows itself in labour market division also, in contrasts concerning workers' compensation, access to advancements and employment stability. These three components convey diverse weight from nation to nation with regards to choices about outsourcing. Therefore, the loss of jobs of public employees may differ in different countries. Rom and Tukel (2012) also argue that the number of the labourers who will be affected is most probably going to determine the choice to contract out a function or service. He presumed that the assurance of whether the quantity of labourers affected has a positive or negative impact on the outsourcing choice is put forth on a defence by case premise, therefore, the displacement of employees and the social impacts that come with it are not guaranteed for every outsourcing contract.

Quality shading: Quality as explained by Dolley (2014) is the "totality or characteristics of services, goods and materials that satisfy the intended need at the lower cost. It is fitness, merit and excellence". Tayauova (2012) postulates that one of the reason to contract out is the desire of getting improved services from the outside provider over in-house group. The outside provider must be picked in that specific approach to 
guarantee that there is no negative effect on the nature of the services provided, if not, the contractor (In this case the local authority) may lose its share in the market due to poor quality services. Holmstrom and Milgrom (1991) in Jensen and Stonecash (2012) developed the multi-tasking approach that highlights that in cases where a private provider is required to multi-task, effort will be given to the tasks that can be measured reliably and easily and resultantly given rewards. The private provider might decide to make increments in productivity while compromising output quality. Jensen and Stonecash (2012) then went on to explain that when there is an incomplete contract, an outside provider has more grounded motivating forces both to decrease costs and enhance service quality than the LA since the private sector firms bore all their loses. However, reducing the costs may compromise quality enhancements and if quality is hard to put down in values, the private firm might have the ability to decrease the quality and not be detected.

In the research done by Wachira et al. (2016), respondents indicated that they were concerned with the quality of services that were being provided in their areas following the adoption of outsourcing. This shows that outsourcing can cause a shading in quality as respondents were showing that when the services were being produced in-house they were getting better services. Private firms that were used to provide the services were not maintaining the quality of services. Dolley (2014) cited that private firms go for profit increases paying special attention on minimising production costs while excluding factors such as service quality. Service quality suffers because private firms are after maximising their profits. However, Goldsmith (2014) argue that outsourcing brings about improved service quality. Aik (2016) researched on the quality of service delivery through outsourcing and concluded that among the other benefits of outsourcing, the employing company (the local authority) has a tendency to diminish the levels and volumes of business exercises to a more common-sense quality service level through concentrating on the core functions of the organisation. This is accomplished on the grounds that superfluous scattering of effort and money on noncore capability are reduced. Figs and Griffith (2012) contend that the industry commission had gotten confirmation that aggressive offering of tenders and outsourcing gives a chance to enhance the quality of the services to be delivered through a superior comprehension of value prerequisites through formal determination, more noteworthy flexibility in picking the organisation to provide the service. This enables the LAs to utilise expert suppliers that spend significant time in that specific function and that concentrate more on quality on account of the danger of losing an agreement. Private firms frequently give more prominent attention to customer needs and more motivating force to create inventive strategies for providing services. Poutvaara (2014) argues that the influence of outsourcing by the LG on service quality depends on the type of service to be contracted. Outsourcing for the most part diminishes costs without harming quality for services that are anything but difficult to institutionalize, similar to trash gathering. Rom and Tukel (2012) assert that due to outsourcing, there will be realization of the same quality services compared to when it was being provided by the local authority. However, the services will be realised at lower overall cost, implying that outsourcing has no impact on service quality but the same services will be enjoyed at a lower overall cost.

Determine Whether There Will be a Relationship Between Outsourcing Service Delivery and the Quality of Services to be Delivered: Blondal (2012) postulates that the factors to consider for vendor selection are the quality of services that the vendors provide, price quoted and budgeted cost by the local authorities. The measure for quality of the services used is the level of consumer satisfaction as Waweru (2014) explains that customer satisfaction translates to quality services. Aik (2016) also argues that outsourcing of any form is a contemporary administration approach whose aim is to lessen cost of operating, enable associations to give careful consideration to their most important functions and enhance the provision of services in addition to other things. He went ahead to state that it can be seen in that, the enhancement of quality for the services is one of the basic elements of the outsourcing idea. Tafirei (2012) noted that a relationship exists between outsourcing and service quality. They found that there was a significant improvement in the quality of services as a result of outsourcing. Through their research, respondents agreed that outsourcing is more efficient in providing quality services through more experience, better qualification and more hard work that comes from the private firms providing the services (Wadesango et al., 2016). Yeboah (2013) conducted a research to determine the relationship between outsourcing and product or service delivery and found out that there is a relationship between the two. He cited that the coefficient of the correlation between the two was 0.2181 which showing a weak relation between contracting out and service quality. If there is a change in outsourcing, there will also be a change in service quality, he then concluded 
that contracting out and service quality have a strong relationship. Increases or decreases in outsourcing will result in the increase and decrease in the quality of services.

Figgis and Griffith (2012) reported that there was evidence that aggressive offering of tenders and outsourcing gives a chance to enhance the quality of the services to be delivered showing that there is a relation between outsourcing and quality of service delivery. They also cited that contracting out allows for an improvement in service quality through a formal determination and more noteworthy adaptability in picking the organisation to provide the service. This enables the LAs to utilise expert suppliers that spend significant time in that specific function and that concentrate more on quality on account of the danger of losing an agreement. Johnson (2014) found that many types of outsourcing include exchanges regarding the quality of the service and proposes that a want for enhanced provision of services isn't the main inspiration for contracting out public services. This came about after the authors saw that the respondents to their research were not satisfied with the services that were being provided through contracting out. Therefore, there was no relationship between outsourcing and the improvement in the service delivery quality as the improvement may not be the aim of the local authorities when they contract out.

Kakabadse and Kakabadse (2012) articulate that in spite of the more elevated amounts of operational abilities in the value-based administration of outsourcing contracts, senior manages in local authorities confirm the notion that the delivery of services had not benefited from contracting out. Comparing the thoughts of the managers of local authorities, there hasn't been a relation between service delivery and outsourcing but rather outsourcing has led to a number of negative impacts such as loss of know-how and expertise in accommodating specific services, loss of innovation, disappointing use of in-house staff among others. Waweru (2014) showed no correlation between outsourcing services and service quality. He first explained that customer satisfaction demonstrates how firms are resolved to give quality services to their clients which, in the long run increases client unwaveringness Therefore, quality services translate to customer satisfaction. Then he showed that correlation between performance and services delivery shows that there is a strong positive correlation, while correlation between productivity and service delivery shows that is a strong negative correlation. A correlation between customer satisfaction and outsourced service delivery show that there is a weak positive correlation that is significant and this implies that the increase or decrease in independent variables would not significantly affect the customer satisfaction (service quality).

Khazei and Keshtegar (2013) researched on the relationship between outsourcing services of health and the satisfaction of the citizens. They found the correlation coefficient of outsourcing services and citizens' satisfaction to be equal to $r=0.90$, that is meaningful in reliability level of $99 \%$. They then went on to research on whether there is a relationship between quality of services and satisfaction of citizens. The results showed a significant and positive relationship between the two. Dahlstrom et al. (2016) assert that contracting out of the provision of services is adversely connected with the nature of the delivery of services, measured as consumer fulfilment with services. It further emerged that the greatness of the negative effect is alleviated by the nature of the municipality workers. Thusly, if outsourcing has antagonistic results for benefit quality yet for instance constructive outcomes on cost diminishment, constructive thinkers might need to figure out how to balance these two critical objectives. Juraj et al. (2012) concluded that contracting may but need not have an influence on decisions by each person, satisfactory provision of services, equity and to an extent controlling expenses as well. Abe and Monisola (2014) also argued that there are difficulties in measuring service quality due to unique natures of services and therefore a relationship between outsourcing and quality of services cannot be determined.

\section{Conclusion}

The aim of this study was to evaluate whether it would be feasible to use outsourcing as a way to better the delivery of services by local authorities in a developing country. It took special attention on the findings by other researchers concerning objectives that had been set by the researchers in this study. Sources such as scholarly journals, the internet and publications were used to obtain information on what other authors had researched on. The underlying objectives were to determine the causes of the current poor service delivery by local authorities and to determine whether outsourcing would be able to overcome these causes and provide for benefits concerning service delivery. This study concludes that corruption, lack of funds, lack of 
citizen participation and political interference are causes of poor services delivery by local authorities. The desk top study has shown that quality services and affordable services can be benefits of outsourcing services.

\section{Recommendations}

- Local authorities should strive to be independent of politicians and their influence on the affairs and policies that concern local authorities by employing elected delegates that are skilled to work in the local authorities as they will be able to act in a manner that is best for the local authority and not for political agendas.

- Local authorities should start engaging in revenue generating activities and projects so as not to depend on the financial assistance from the central government.

\section{References}

Abe, T. \& Monisola, O. J. (2014). Citizen participation and service delivery at the local government level: a case study of Ise/ Orun local government. Journal of law, policy and globalization, 27, 34-43

Aik, A. M. (2016). Using quality of service delivery to evaluate federal government of Nigeria policy on public service outsourcing: a case of public healthcare institutions, Nigeria. International journal of academic research in business and social sciences, 6(5), 76-87

Ame, A., Chaya, P. \& John, P. (2013). Underfinancing in local government authorities of Tanzania and cause of effects: a case of Bahai district council. Global journal of human social sciences economics, 13(1), 56-65

Bazeley, P. (2015). Mixed methods in management research: implications for the field. The electronic journal of business research methods, 13(1), 34-43

Blondal, R. J. (2012). Market type mechanisms and the provision of public services. OECD journal on budgeting, 5(1), 34-45

Boris, H. O. (2015). Challenges confronting local governments administration in effective and efficient social service delivery: The Nigerian experience. International journal of public administration and management research (IJPAMR),2(5), 78-98

Cox, M., Roberts, M. \& Walton, J. (2012). It outsourcing in the public sector local government. The electronic journal information systems evaluation,15(3), 79-87

Dahlstrom, C., Nistotsaya, M. \& Tyrberg, M. (2016). Is the quality of the outsourced public services contingent on the quality of bureaucracy? QOG The quality of government institute. Working paper series 2016:10.

Dolley, B. (2014). Outsourcing and insourcing in Australian local government. Public infrastructure report and municipal road maintenance and renewal, Briefing paper 22(12)

Ejue, E. A. \& Madudueze, M.C. (2014). Corruption and service delivery in local government system in Nigeria: a content analysis. International journal of business science,5(10), 23-32

Fernandez, S., Smith, R. C. \& Wenger, J. B. (2012). Employment, privatisation and managerial choice: does contracting out reduce public sector employment? Journal of policy analysis and management. 26(1), 187-198

Figgis, H. \& Griffith, G. (2012). Outsourcing in the public sector. Briefing paper, 22(12)

Goldsmith, J. (2014). Government outsourcing: a practical guide for safe and local governments. India: School of public and environmental affairs Press

Grant, K. J. \& Ohemeng, F. L. (2014). Neither public or private: the efficacy of mixed model public service delivery in 2 Canadian municipalities. Canadian public administration,57(4), 43-54

Greenwood, D. T. (2014). The decision to contract out: understanding the full economic and social impacts. Colorado: Centre for Policy Studies.

Grossi, G. \& Mussari, R. (2012). Effects of outsourcing on performance measurement and reporting: the experience of Italian local governments. Public budgeting and finance.

Hassan, A., Roberts, M. S. \& Joy, A.U. (2013). Local government service delivery in Nigeria: an empirical comparison of government efforts and the people's expectations. Mediterranean journal of social sciences, $4(6), 89-97$

Ibok, E. E. (2014). Local governance and service delivery in Nigeria. Caribbean journal of science and technology, 2, 536-541 
Irish, L. E., Salamon, L. M. \& Simon, K. W. (2012). Outsourcing social services: lessons from abroad. Final June report.

Jensen, P. H. \& Stonecash, R. E. (2012). The efficiency of public sector outsourcing contracts. Journal of economic surveys, $19(5), 76-89$

Johnson, P. M. (2014). Secondary data analysis: a method of which the time has come. Qualitative and quantitative methods in libraries (QQML), 3(1), 56-75

Juraj, N., Merickova, B. M. \& Zuzana, V. (2012). Management of contracting public services and its quality in Slovakia. The NISPAcee journal of public administration and policy,5(1), 23-34

Kakabadse, A. \& Kakabadse, N. K. (2012). Outsourcing in the public services: a comparative analysis of practice, capability and impact. Nigeria: Public administration and development Press

Kinyua, K. B. (2015). Determinant of outsourcing services as a cost reduction measure in devolved government: a case study of Nairobi city county, Kenya. European journal of business and social sciences, 4(5), 56-76

Khazei, A. \& Keshtegar, A. (2013). The study on the relationship between outsourcing services of health notebook issuance with satisfaction of citizens. European online journal of natural and social sciences, $2(3), 67-78$

Ketch, C. C. (2013). Trends in the contracting out local government services. Graduate thesis and dissertations, University of South Florida.

Kurdi, M. K. (2012). Outsourcing in facilities management- a literature review. Procedia Engineering, 2, 34-56

Macanda, A. S. (2014). An analysis of rural development in the eastern cape: a case study of Intsika Municipality. McS, University of Western Cape.

Makanyeza, C. (2015). Consumer Awareness, Ethnocentrism and Loyalty: An Integrative Model. Journal of International Consumer Marketing, 27(2), 67-98

Majekodunm, A. (2012). The state of local government and service delivery in Nigeria: changes and prospects. Africa's public service delivery and performance review.

Majikijela, M. (2012). Service delivery and service payment at Emafuleni local municipality. A minidissertation submitted in partial fulfilment of the requirements for the degree in Development and Management North-West University

Poutfelt, F. (2014). Outsourcing service production in the public sector: are we addressing the right question? Danish journal of management and business, 3(4), 23-43

Poutvaara, P. (2014). The desirability of outsourcing in the provision of public services depends on the characteristics and market condition. Public sector outsourcing. Germany: University of Munich.

Rom, W. \& Tukel, O. (2012). Outsourcing decision support: a survey of benefits, risks and decision factors. Supply chain management: an international journal, 11(6), 56-78

Salam, H., Pirannejad, A. \& Mollaee, A. (2012). Outsourcing piorities of government functions: Analytic networs process approach. African journal of business management, 4(9), 87-98

Tafirei, F. (2012). The quality of service delivery in Zimbabwean urban councils: a case of Bindura municipality (2010-2012).Bindura University of Science Education, 5, 67-89

Tayauova, G. (2012). Advantages and disadvantages of outsourcing. Procedia-social and behavioural sciences, $41,56-87$

Tynkkynen, N., Juhani, L.\& Sari, M. (2012). Framing the decision to contract out elderly care and primary health care services perspectives of local level politicians and civil servants in Finland. BMC health services research, 12, 89-97

Wachira, W., Brooke, M. \& Haines, R. (2016). Viewing the impact of outsourcing from a Kenyan perspective. Asian journal of management social and economics, 3(1), 54-78

Wadesango, N. \& Mhaka, C. (2017). The Effectiveness of Enterprise Risk Management and Internal Audit Function on Quality of Financial Reporting in Universities. Journal of Economics and Behavioral Studies, 9(4), 230-241

Wadesango, N., Mhaka, C.\& Wadesango, V.O. (2017). Contribution of enterprise risk management and internal audit function towards quality of financial reporting in universities in a developing country. Risk Governance and control: Financial markets \& institutions,7(2), 170-176

Wadesango, N., Mhaka, C., Chinamasa, T.\& Wadesango, O.V. (2017). An investigation into Management's reluctance in implementing Audit recommendations and its effects to risk. Corporate Board: Role, Duties \& Composition,13(2), 61-70 
Wadesango, N.\& Wadesango, O. (2016). The need for financial statements to disclose true business performance to stakeholders. Corporate Board: Role, duties and composition,12(2), 77-84

Wadesango, N., Tasa, E., Milondzo, K.\& Wadesango, V.O. (2016). An empirical study of the influence of IAS/IFRS and regulations on quality of financial reporting of listed companies. Risk Governance and control: Financial markets \& institutions, 6(4), 76-83

Waweru, K. D. (2014). The impact of outsourcing startegy on service delivery in Niarobi County. Msc administartion at the university of Nairobi.

Yeboah, A. (2013). The relationship between outsourcing and organisational performance. European journal of business and management, 5(2), 78-98

Zhang, M. \& Sun, J. (2012). Outsourcing in Municipal Governments. Public performance and management review, 5(4), 696-726. 